\title{
OBITUARY
}

\section{DOROTHY Feyer}

Dr Dorothy Feyer, a founder member of the British Society for the History of Science, died on 9 March 1974, aged 82, after a long illness.

Dorothy Mabel Turner, daughter of Arthur James Turner, an architect, was born in Tottenham on 6 February 1892. Educated at Dame Alice Owen School, Islington, she studied physical sciences at Bedford College, graduated B.Sc. at London in 1913, and obtained a Certificate of Paedagogy from the London Day Training College. While teaching science she took her London M.A. (1922) with a thesis on an educational subject, and by the mid-rg2os she was head of the science department at Wycombe Abbey. While continuing to hold this post, she became in 1925 one of the first two Honorary Research Assistants to Charles Singer, who was then Lecturer in the History of Medicine at University College, London. She continued to hold this honorary post until the session $1928-9$.

In 1927 she published, under the name D. M. Turner, Makers of science, electricity $\mathcal{E}$ magnetism. (All her subsequent writings bore this name.) Later in 1927 she published History of science teaching in England, a valuable book which is not sufficiently known. In 1928 she submitted this book and five subsidiary papers and graduated Ph.D. of London University. In I933 she published The book of scientific discovery, intended for schools and non-technical readers. (There was a second, enlarged, edition in 1952.) Many years later she wrote at my invitation a valuable essay, in honour of Charles Singer, entitled 'Thomas Young on the eye and vision', published in Science, medicine and history in I953.

In February I 928 she married Otto Fejer, a lawyer of Bratislava. (The spelling was later silently anglicized to Feyer for ordinary British purposes.) From $193^{\circ}$ to July $193^{8}$ she was Lecturer in English in the University of Bratislava. She and her husband returned to London during the summer of 1938; in September she was appointed Lecturer in Educational Psychology at the Maria Grey Training College, and on the outbreak of war she taught also the physical sciences. She became a Senior Lecturer in 1949 , and in 1956 one of the four Principal Lecturers. Her husband had died in October 1946, and from about 1953 until her retirement in 1959 she was also the Warden of a Hall of Residence and lived in the College. When she retired she at once took on the part-time post of Lecturer in Education and Supervisor of the SisterTutors' Diploma Course at Queen Elizabeth College, from which she retired in 1968 .

I well remember proposing Dr Feyer, at a preliminary meeting early in I 947 before the actual foundation meeting of the British Society for the History of Science, as a member of the Original Council. She was elected, and she served on the Council from 1947 to I95 I, from 1954 to 1960 , and from 1963 to 1967 -fourteen years in all.

Dr Feyer was a gifted painter, both in oils and water-colours, but the crippling arthritis from which she suffered in her last years made increasingly difficult her devotion to this life-long interest.

\section{E. Ashworth Underwood}

